\title{
IDENTIFIKASI KENDALA DALAM PROSES PRODUKSI DAN DAMPAKNYA TERHADAP BIAYA PRODUKSI PADA UD. RISKY
}

\author{
Intan Purwatianingsih Sihadi ${ }^{1}$, Sifrid S. Pangemanan ${ }^{2}$, Hendrik Gamaliel ${ }^{3}$ \\ 1,2,3 Jurusan Akuntansi, Fakultas Ekonomi dan Bisnis, Universitas Sam Ratulangi, Jl. Kampus Bahu, Manado, \\ 95115, Indonesia \\ E-mail : intaninpurz@gmail.com
}

\begin{abstract}
Constraints are activities that prevent companies from carrying out production activities. Along with the increasingly competitive world economy today, industrial companies are required to be more sensitive in anticipating constraints that occur both internally and externally. These constraints must be considered by the company because it can hamper the production process which has an impact on production costs as well as sales volumes which ultimately cause losses to the company. One tool that can identify constraints of a company is the Constraint Theory. This study aims to find out what constraints occur in the production process and the impact of these constraints on production costs. The method used in this study is descriptive. The results of this study are internal constraints are engine damage and external constraints are delays in the delivery of raw materials. The impact of these constraints on production costs is the loss of raw material costs and an increase in factory overhead costs.
\end{abstract}

Keywords: Constraints, Production Cost, Theory of Constraint

\section{PENDAHULUAN}

Sebuah perusahaan industri dalam menjalankan kegiatan produksinya memerlukan beberapa sumber daya ekonomi, seperti bahan baku, sumber daya manusia, modal, fasilitas yang harus dapat dialokasikan dan dimanfaatkan secara optimal. Pada nyatanya, setiap perusahaan mengalami keterbatasan sumber daya produksi yang disebut kendala atau constraint. Kendala memiliki dampak terhadap profitabilitas perusahaan. Kendala adalah segalah hal yang dapat menghambat perusahaan dalam melakukan kegiatan produksi. Seiring dengan perkembangan dunia perekonomian dewasa ini yang semakin kompetitif, perusahaan industri dituntut untuk lebih peka dalam mengidentifikasi dan mengantisipasi kendalakendala yang terjadi baik yang bersifat internal dan eksternal. Namun, pada nyatanya masih banyak perusahaan yang tidak memberikan perhatian khusus pada kendala yang terjadi, khususnya pada kegiatan produksi. Kendala tersebut harus diperhatikan oleh perusahaan karena dapat menghambat proses produksi yang berdampak pada biaya produksi juga volume penjualan yang akhirnya menyebabkan kerugian pada perusahaan.

Salah satu teori yang dapat digunakan untuk mengidentifikasi kendala adalah Teori Kendala. Teori Kendala adalah pendekatan yang digunakan oleh perusahaan untuk mengidentifikasi, mengeksploitasi dan menemukan cara untuk mengatasi kendala yang terjadi dalam proses produksi. Teori Kendala mengakui bahwa kendala terjadi pada setiap perusahaan dan dapat menghambat peningkatan kinerja perusahaan (Hansen dan Mowen, 2000 : 606). UD. Risky merupakan perusahaan yang bergerak dibidang manufaktur. Produk yang dihasilkan oleh perusahaan adalah kasur tidur. Perusahaan memasarkan produknya hingga ke luar kota seperti Gorontalo, Talaud, Sanger, Kotamobagu, Ternate, dan lain-lain. Perusahaan menggunakan sumber daya mesin sebagai sumber daya utama dan tenaga manusia sebagai pengawas proses produksi. Sebagai perusahaan yang memproduksi kasur, UD. Risky menghadapi beberapa kendala dalam kegiatan produksi. Dan tidak menutup 
kemungkinan bahwa ada kendala lain yang terjadi, namun tidak teridentifikasi oleh perusahaan. Adapun tujuan dari penelitian ini adalah (1) untuk mengidentifikasi kendalakendala yang terjadi pada UD. Risky; (2) untuk mengetahui dampak kendala tersebut pada biaya produksi; (3) untuk menemukan bagaimana solusi untuk menyelesaikan kendala tersebut.

\section{TINJAUAN PUSTAKA}

Pengertian Akuntansi. Menurut Warren et al., (2014:3) akuntansi menyediakan informasi dalam bentuk laporan keuangan untuk pihak-pihak yang memiliki kepentingan terkait aktivitas ekonomi dan kondisi perusahaan. Akuntansi adalah ilmu yang mempelajari proses pengidentifikasian, pengelompokkan, pencatatan, dan pelaporan informasi yang bersifat keuangan, yang akan digunakan oleh pihak-pihak yang memiliki kepentingan baik pihak eksternal perusahaan maupun pihak internal perusahaan.

Pengertian Akuntansi Manajemen. Menurut Indriani (2018 : 2) akuntansi manajemen adalah suatu kegiatan (proses) yang kemudian akan menghasilkan informasi keuangan bagi pihak internal perusahaan yang memiliki kepentingan yaitu manajemen untuk pengambilan keputusan ekonomi dalam melaksanakan fungsi manajemen. Adapun menurut Krismiaji dan Aryani (2011 : 1) akuntansi manajamen adalah salah satu cabang ilmu dalam akuntansi yang menghasilkan output berupa informasi keuangan untuk pihak intern perusahaan seperti manajemen. Akuntansi manajemen adalah suatu ilmu yang mempelajari proses mengidentifikasi, mengumpulkan, mengukur, mengklasifikasi, mencatat dan melaporkan transaksi hingga menjadi sebuah informasi yang dikhususkan bagi pengguna internal untuk pengambilan keputusan.

Perbedaan Akuntansi Manajemen dan Akuntansi Keuangan. Akuntansi Keuangan memiliki fokus eksternal dengan mengikut aturan tertentu, sedangan akuntansi manajemen memiliki fokus internal dan tidak ada aturan yang mengikat (Hansen dan Mowen 2009 : 11). Akuntansi manajemen menghasilkan laporan keuangan yang digunakan oleh pihak internal perusahaan dalam hal ini manajemen perusahaan untuk pengambilan keputusan. Laporan keuangan yang dihasilkan bersifat rinci dengan rentang waktu yang fleksibel mulai dari harian, mingguan, bulanan, bahkan dapat mencapai periode sepuluh tahun. Sedangkan akuntansi keuangan menghasilkan laporan keuangan yang akan dipakai oleh pihak eksternal perusahaan, seperti investor, kreditur, dan pemerintah. Dalam akuntansi keuangan, ketepatan informasi merupakan hal yang penting dan laporan yang dihasilkan menggambarkan perusahaan secara keseluruhan.

Pengertian Biaya. Menurut Mulyadi (2014 : 8) biaya adalah pengorbanan sumber ekonomi, yang dihitung dalam satuan uang untuk ditukar dengan barang dan jasa, yang telah terjadi atau kemungkinan akan terjadi untuk tujuan tertentu. Biaya adalah suatu pengorbanan, pengeluaran atau nilai tukar dalam satuan uang yang dilakukan untuk memperoleh manfaat baik untuk waktu sekarang ataupun masa depan demi tercapainya tujuan tertentu dalam suatu organisasi.

Penggolongan Biaya. Biaya digolongkan menjadi: objek pengeluaran, fungsi pokok perusahaan, hubungan biaya dengan sesuatu yang dibiayai, perilaku dalam hubungannya dengan perubahan volume aktifitas, jangka waktu manfaatnya.

Pengertian Biaya Produksi. Menurut Carter (2013 : 40) biaya manufaktur atau biasa disebut dengan biaya produksi atau dengan nama lain biaya pabrik, merupakan hasil penjumlahan dari tiga jenis biaya yaitu biaya bahan baku langsung, biaya tenaga kerja langsung, biaya overhead pabrik. Biaya produksi adalah suatu pengeluaran atau pengorbanan yang dilakukan untuk mengubah bahan baku menjadi bahan setengah jadi hingga menjadi produk jadi.

Elemen Biaya Produksi. Elemen-elemen biaya produksi adalah: biaya bahan baku langsung, biaya tenaga kerja langsung, biaya overhead pabrik. 
Teori Kendala. Kendala merupakan semua hal yang terjadi yang dapat menghambat kegiatan produksi sehingga menyebabkan kerugian bagi perusahaan (Blocher, Cokins dan Stout, 2014 : 189). Menurut Blocher, dkk (2007 : 21) teori kendala merupakan teknik strategis yang digunakan untuk membantu perusahaan dalam memperbaiki CSF (critical success factors) secara efektif yang dinilai sangat penting: waktu siklus, yakni tingkat kecepatan bahan baku diubah menjadi produk jadi. Teori kendala adalah metode, pendekatan dan alat yang digunakan untuk memaksimalkan pendapatan dengan cara mengidentifikasi kendala yang terjadi selama proses produksi kemudian menganalisis cara untuk mengatasi kendala tersebut.

Jenis-jenis Kendala. Menurut Setyaningrum dan Hamidy (2008 : 28) jenis kendala dapat dibedakan menjadi: kendala internal, kendala eksternal, kendala kendur dan kendala mengikat.

Konsep Dasar Teori Kendala. Konsep dasar teori kendala adalah sebagai berikut: Throughput adalah ukuran pada penghasilan yang didapatkan oleh perusahaan melalui kegiatan penjualan. Persediaan adalah semua yang dimiliki dan tersedia secara potensial yang dikeluarkan oleh perusahaan untuk mengubah bahan baku menjadi throughput. Biaya operasional adalah semua pengorbanan yang dikeluarkan oleh perusahaan untuk mengubah persediaan menjadi throughput.

Langkah-langkah pada Teori Kendala. (1) mengidentifikasi kendala; (2) menentukan dan merancang kegiatan produksi yang paling baik ketika dihadapkan dengan kendala; (3) memaksimalkan kegiatan produksi dengan kendala yang terjadi; (4) meningkatkan daya tahan ketika menghadapi kendala; (5) merancang kembali proses produksi.

Kajian Penelitian Terdahulu. Restriani (2011) melakukan penelitian dengan judul Analisis Biaya Produksi Dengan Pendekatan Theory of Constraint (TOC) (Studi Kasus di PT. Mitra Lestari Abadi (MLA) Banyumas). Penelitian ini bertujuan untuk menerapkan Teori Kendala dan dampaknya pada biaya produksi pada bulan November-Desember tahun 2011 di PT. Mitra Lestari Abadi (MLA) Banyumas. Metode penelitian yang digunakan adalah kualitatif. Hasil dari penelitian ini menunjukkan penerapan teori kendala dapat meminimalkan biaya produksi, atau dengan kata lain, penerapan teori kendala berpengaruh terhadap jumlah biaya produksi.

\section{METODE PENELITIAN}

Jenis Penelitian. Jenis penelitian yang digunakan penulis pada penelitian ini adalah penelitian kualitatif dengan pendekatan deskriptif. Menurut Moleong (2011 : 6) penelitian kualitatif adalah penelitian yang bertujuan untuk memahami kejadian yang terjadi dalam atau oleh subjek yang diteliti, menggunakan cara deskripsi yaitu penggunaan kata dan bahasa pada sebuah konteks khusus yang alamiah dengan memanfaatkan bermacam-macam metode alamiah.

Tempat dan Waktu Penelitian. Penelitian ini dilaksanakan di UD. Risky yang beralamat di Jalan Paniki Atas. Waktu dimulainya penelitian adalah pada bulan Mei 2018 s/d selesainya.

Jenis Data Penelitian. Jenis data yang digunakan dalam penelitian ini adalah: data kualitatif dalam penelitian ini adalah jenis kendala yang terjadi baik kendala internal maupun kendala eksternal dan proses produksi dan dampak kendala tersebut pada biaya produksi dan data kuantitatif dalam penelitian ini berupa data anggaran dan realisasi biaya lembur tenaga kerja langsung pada tahun 2017.

Sumber Data Penelitian. Sumber data yang digunakan dalam penelitian ini adalah: sumber data primer yang digunakan dalam penelitian adalah jenis kendala yang terjadi, dampak kendala pada biaya produksi, dan proses produksi dan sumber data sekunder yang digunakan dalam penelitian ini adalah sumber buku, jurnal yang terkait dengan penelitian dan anggaran dan realisasi biaya lembur tenaga kerja langsung tahun 2017. 
Metode Pengumpulan Data. Metode pengumpulan data yang digunakan dalam penelitian ini adalah:

1. Wawancara akan dilakukan kepada pemilik UD. Risky. Wawancara dilakukan untuk mengetahui kendala apa saja yang terjadi dalam perusahaan baik kendala internal maupun kendala eksternal dan apa dampak kendala tersebut terhadap biaya produksi.

2. Observasi merupakan pengamatan langsung yang dilakukan oleh peneliti terkait proses produksi dan kendala pada proses produksi benar terjadi.

3. Dokumentasi dalam penelitian ini adalah rekap anggaran dan realisasi biaya lembur tahun 2017 UD. Risky untuk melihat dampak kendala yang terjadi pada biaya produksi.

Metode dan Proses Analisis. Metode analisis yang digunakan dalam penelitian ini adalah metode analisis deskriptif. Metode deskriptif adalah metode yang bertujuan untuk mendeskripsikan atau menggambarkan dan menerangkan data yang kemudian dioleh sehingga dapat membuat suatu kesimpulkan berdasarkan informasi dan data yang berhasil dikumpulkan. Proses analisis yang akan dilakukan adalah:

1. Tahap pertama, penulis melakukan pengumpulan data melalui kegiatan wawancara yang dilakukan kepada pemilik perusahaan untuk mengetahui kendala yang terjadi, selain itu penulis juga melakukan observasi untuk melihat kegiata produksi dan mengkonfirmasi kendala yang terjadi pada proses produksi, dan kegiatan terakhir adalah dokumentasi guna melihat dampak kendala yang terjadi pada biaya produksi.

2. Tahap kedua, penulis membahas hasil data yang telah penulis dapatkan.

3. Tahap ketiga, penulis mengidentifikasi kendala internal dan eskternal pada proses produksi yang terjadi pada UD. Risky dengan menggunakan konsep Teori Kendala berdasarkan hasil wawancara dengan pemilik perusahaan dan hasil observasi yang penulis lakukan. Selanjutnya penulis menganalisis dampak kendala yang terjadi pada biaya produksi yang dikeluarkan oleh perusahaaan berdasarkan hasil dokumentasi.

4. Tahap keempat, penulis menarik kesimpulan terkait kendala internal dan eksternal pada proses produksi yang terjadi pada UD. Risky dengan konsep Teori Kendala dan dampak kendala tersebut pada biaya produksi.

5. Tahap kelima, penulis memberikan saran kepada perusahaan bagaimana menyelesaikan kendala ataupun meminimalisir kendala yang terjadi.

\section{HASIL PENELITIAN DAN PEMBAHASAN}

4.1. Hasil Penelitian

Identifikasi Kendala. Dari hasil wawancara dan observasi yang dilakukan maka dapat diidentifikasikan kendala yang terjadi terbagi atas kendala internal dan kendala eksternal. Adapun pembahasan mengenai kendala tersebut adalah sebagai berikut.

Kendala Internal : Kerusakan Mesin. Pada wawancara dengan Bapak Ronald selaku pemilik perusahaan, beliau menyampaikan bahwa kendala internal yang terjadi pada UD. Risky adalah kelalaian tenaga kerja langsung. Kendala ini kemudian berimplikasi pada kesalahan timbang bahan baku. Adapun penyebab kendala ini menurut perusahaan adalah kurangnya ketelitian dari tenaga kerja langsung dalam melakukan proses penimbangan bahan baku yang akan digunakan.

Namun, pada observasi yang penulis lakukan guna untuk mengkonfirmasi kendala yang terjadi, didapati bahwa tenaga kerja yang melakukan proses penimbangan sudah sangat hatihati dalam melakukan proses ini dan hasil yang tidak konsisten pada mesin timbangan yang digunakan. Untuk itu dapat disimpulkan bahwa, kendala internal yang terjadi pada perusahaan adalah kerusakan mesin berupa mesin timbangan digital yang kemudian berimplikasi pada kesalahan timbang bahan baku yang digunakan.

Kendala Eksternal : Keterlambatan Pengiriman Bahan Baku. Pada hasil wawancara dengan Bapak Ronald selaku pemilik perusahaan, didapatkan informasi bahwa kendala 
eksternal yang terjadi pada perusahaan adalah keterlambatan pengiriman bahan baku yang berimplikasi pada terhentinya kegiatan produksi selama beberapa hari. Penulis kemudian melakukan observasi untuk mengkonfirmasi kendala eksternal yang terjadi. Pada hasil pengamatan yang penulis lakukan selama dua hari terlihat kegiatan pabrik sangat senggang. Selain itu drum yang biasa digunakan untuk menampung bahan baku terlihat kosong. Persediaan barang jadi berupa kasur untuk ukuran tertentu juga habis dan stok untuk beberapa ukuran lainnya menipis. Tenaga kerja yang melakukan proses menjahit dan packing, memulai kegiatan produksi pada jam 13.00 dan telah diperbolehkan pulang pada jam 16.00 WITA. Untuk itu dapat disumpulkan bahwa, kendala eksternal yang disampaikan oleh perusahaan, benar terjadi dan sangat mengganggu pada kegiatan produksi.

Dampak Kendala Internal Terhadap Biaya Produksi. Kesalahan proses produksi menyebabkan adonan kasur rusak ketika mengalami proses pencetakan. Adonan yang rusak biasanya sudah tidak dapat digunakan lagi atau harus dibuang. Hal ini menyebabkan kerugian bagi perusahaan.

Dampak Kendala Eksternal Terhadap Biaya Produksi. Seperti di bahas sebelumnya, kendala eksternal yang dihadapi perusahaan adalah keterlambatan pengiriman bahan baku yang berimplikasi pada terhentinya proses produksi yang berdampak pada tidak terpenuhinya permintaan pasar dan menurunnya profitabilitas perusahaan. Berikut dampak kendala eksternal terhadap biaya produksi pada Tabel 1.

Tabel 1. Kerugian Keterlambatan Pengiriman Bahan Baku

\begin{tabular}{|c|c|c|c|c|c|}
\hline Bulan & $\begin{array}{l}\text { Jumlah } \\
\text { Jam Kerja } \\
\text { (Jam) }\end{array}$ & $\begin{array}{c}\text { Jumlah Jam } \\
\text { Berhenti } \\
\text { Produksi } \\
\text { (Jam) }\end{array}$ & $\begin{array}{c}\text { Biaya Tenaga } \\
\text { Langsung per } \\
\text { Orang per Jam } \\
(\mathbf{R p})\end{array}$ & $\begin{array}{c}\text { Biaya Tenaga } \\
\text { Kerja Langsung } \\
\text { per Jam } \\
(\mathbf{R p})\end{array}$ & Kerugian \\
\hline Juni & 184 & 42 & 19.021 & 209.293 & 8.790 .306 \\
\hline Juli & 208 & 18 & 16.826 & 185.096 & 3.331 .728 \\
\hline Agustus & 200 & 12 & 17.500 & 192.500 & 2.310 .000 \\
\hline September & 192 & 7 & 18.229 & 200.520 & 1.403 .640 \\
\hline Oktober & 208 & 2 & 16.826 & 185.096 & 370.193 \\
\hline November & 208 & 8 & 16.826 & 185.095 & 1.480 .768 \\
\hline Desember & 168 & 43 & 20.833 & 229.166 & 9.854 .138 \\
\hline
\end{tabular}

Selain itu, terhentinya kegiatan produksi menyebabkan perusahaan harus melakukan banyak jam lembur untuk memenuhi permintaan pasar. Hal ini dapat dilihat dari data pada Tabel 2.

Tabel 2. Anggaran dan Realisasi Biaya Lembur UD. Risky Tahun 2017

\begin{tabular}{lrrr}
\hline Bulan & Anggaran Biaya Lembur (Rp) & Realisasi Biaya Lembur (Rp.) & Selisih (Rp) \\
\hline Januari & 2.336 .720 & 2.781 .791 & 445.071 \\
Februari & 2.002 .890 & 2.559 .258 & 556.368 \\
Maret & 2.670 .535 & 3.671 .965 & 1.001 .430 \\
April & 2.336 .710 & 2.791 .801 & 455.091 \\
Mei & 4.005 .780 & 4.673 .410 & 667.630 \\
Juni & 6.008 .670 & 8.456 .647 & 2.447 .977 \\
Juli & 2.447 .976 & 3.894 .508 & 1.446 .532 \\
Agustus & 1.669 .075 & 2.114 .158 & 445.083 \\
September & 2.002 .887 & 2.336 .701 & 333.814 \\
Oktober & 1.446 .529 & 1.891 .615 & 445.086 \\
November & 4.005 .774 & 4.637 .403 & 631.629 \\
Desember & 6.008 .661 & 8.011 .548 & 2.002 .887 \\
\hline
\end{tabular}


Pada Tabel 2. dapat dilihat realisasi biaya lembur selalu melebihi anggaran biaya lembur. Selisih realisasi dan anggaran biaya lembur terbesar terjadi pada bulan Juni dan Desember. Pada bulan Juni anggaran biaya lembur sebesar Rp. 6.008.670 dan realisasinya sebesar Rp. 8.456.647. Dan untuk bulan Desember anggaran biaya lembur sebesar Rp. 6.008.661 dengan realisasi sebesar Rp. 8.011.548. Hal ini disebabkan pada bulan Juni dan Desember terdapat paling sedikit jumlah jam kerja dengan jumlah jam berhenti produksi terbanyak. Jumlah jam kerja yang sedikit disebabkan pada bulan ini terdapat banyak hari libur, dan banyaknya jam berhenti produksi disebabkan keterlambatan pengiriman bahan baku. Jumlah jam kerja yang sedikit ditambah dengan jumlah jam berhenti produksi yang banyak, menimbulkan kenaikan biaya lembur. Hal ini dikarenakan perusahaan berusaha memenuhi permintaan pasar yang tinggi pada bulan-bulan tersebut dengan kendala yang ada yaitu keterlambatan pengiriman bahan baku. Kenaikan biaya lembur menyebabkan meningkatnya biaya produksi sehingga mengurangi profit yang didapatkan oleh perusahaan.

Solusi Kendala. Dilihat dari kendala yang terjadi baik kendala internal maupun kendala eksternal maka solusi yang paling tepat menurut penulis adalah perusahaan dapat memperkerjakan tenaga kerja sebagai kepala bagian produksi dengan tugas untuk mengawasi kegiatan produksi. Selain itu, tenaga kerja tersebut juga dapat difungsikan untuk mengontrol proses pemesanan hingga pengiriman bahan baku, agar sesuai dengan estimasi yang telah ditentukan. Dengan memperkerjakan kepala bagian produksi, maka kendala-kendala yang terjadi pada proses produksi akan lebih mudah dikenali dan dapat dengan segera diatasi. Selain itu biaya tenaga kerja yang dikeluarkan oleh perusahaan jauh lebih sedikit jika dibandingkan dengan kerugian yang dialami oleh perusahaan dikarenakan kendala yang terjadi.

\subsection{Pembahasan}

Setelah mengidentifikasikan kendala yang terjadi menggunakan konsep Teori Kendala, maka didapati kendala yang terjadi pada UD. Risky diantaranya adalah kendala internal yang berupa kerusakan mesin dan kendala eksternal berupa keterlambatan pengiriman bahan baku. Kendala internal yang terjadi pada UD. Risky berupa kerusakan mesin timbangan yang berimplikasi pada kesalahan timbang bahan baku, menyebabkan perusahaan mengalami kerugian pada bahan baku yang digunakan. Terkait kendala eksternal yang terjadi, yaitu keterlambatan pengiriman bahan baku, berimplikasi pada terhentinya proses produksi. Terhentinya proses produksi juga menyebabkan perusahaan harus melakukan kegiatan lembur untuk memenuhi permintaan pasar.

Jika perusahaan melakukan kontrol dengan baik pada proses produksi, maka perusahaan dapat menghindari biaya-biaya yang tidak menambah nilai produk (non value added). Perusahaan dapat menghindari kerugian yang terjadi pada kesalahan timbang bahan baku, apabila perusahaan melakukan kontrol saat kegiatan produksi. Perusahaan dapat memperkerjakan seorang tenaga kerja sebagai kepala bagian produksi dengan tugas untuk mengawasi kegiatan produksi. Selain itu, tenaga kerja tersebut juga dapat difungsikan untuk mengontrol proses pemesanan hingga pengiriman bahan baku, agar sesuai dengan estimasi yang telah ditentukan. Dengan memperkerjakan kepala bagian produksi, maka kendalakendala yang terjadi pada proses produksi akan lebih mudah dikenali dan dapat dengan segera diatasi. Selain itu biaya tenaga kerja yang dikeluarkan oleh perusahaan jauh lebih sedikit jika dibandingkan dengan kerugian yang dialami oleh perusahaan dikarenakan kendala yang terjadi.

\section{KESIMPULAN DAN SARAN}

\subsection{Kesimpulan}

1. Penerapan Teori Kendala dapat digunakan untuk mengidentifikasi masalah atau kendala yang terjadi selama proses produksi. Adapun kendala internal yang dihadapi oleh UD. 
Risky adalah kerusakan pada mesin yang menyebabkan kerugian pada biaya bahan baku dan kendala eksternal yaitu keterlambatan pengiriman bahan baku yang menyebabkan berhentinya proses produksi yang dapat berdampak pada tidak terpenuhinya permintaan pasar yang memaksa perusahaan untuk melakukan kegiatan lembur.

2. Kendala yang terjadi dalam perusahaan berdampak pada biaya produksi. Khususnya pada biaya bahan baku dan biaya tenaga kerja. Kendala internal yang terjadi yaitu kerusakan mesin timbangan yang berimplikasi pada salah timbang bahan baku atau dapat juga disebut sebagai kesalahan proses produksi yang menyebabkan kerugian pada biaya bahan baku, karena kesalahan timbang bahan baku menyebabkan bahan baku tidak bisa digunakan lagi. Kendala eksternal yaitu keterlambatan pengiriman bahan baku berimplikasi pada terhentinya proses produksi yang menyebabkan tenaga kerja non-job dan meningkatnya realisasi biaya lembur yang telah dianggarkan.

3. Solusi yang diberikan atas kendala-kendala yang terjadi adalah perusahaan dapat memperkerjakan seorang tenaga kerja sebagai kepala bagian produksi yang dapat ditugaskan untuk mengontrol proses produksi hingga proses pemesanan bahan baku. Jika dibandingkan antara biaya gaji kepala bagian produksi dengan jumlah kerugian yang dialami perusahaan, maka akan lebih menguntungkan bagi perusahaan karena biaya tenaga kerja lebih kecil dibandingkan dengan kerugian yang dialami perusahaan.

\subsection{Saran}

Berdasarkan kesimpulan diatas maka dapat diberikan saran-saran sebagai berikut:

1. Untuk kelancaran proses produksi, alangkah baiknya perusahaan dapat memperkerjakan seorang tenaga kerja sebagai kepala bagian produksi yang bertugas untuk mengontrol kegiata produksi sekaligus mengawasi kegiatan pemesanan hingga pengiriman bahan baku, agar kendala yang terjadi pada kegiatan produksi dapat dikenali lebih cepat dan diatasi dengan segera.

2. Perusahaan sebaiknya memberikan pengarahan dan sanksi tegas kepada karyawan yang melakukan kesalahan, agar karyawan dapat melakukan tugasnya dengan baik, sehingga dapat menghindari terjadinya kendala dalam proses produksi.

3. Perusahaan sebaiknya melakukan kontrol terhadap seluruh peralatan yang digunakan dalam proses produksi, untuk menghindari kerusakan terhadap peralatan yang tidak diketahui.

4. Perusahaan sebaiknya melakukan kontrol terhadap pengiriman bahan baku baik kepada supplier maupun kepada ekspedisi yang digunakan untuk mengirim bahan baku.

\section{DAFTAR PUSTAKA}

Blocher, Edward J., Kung H. Chen, Gary Cokins, dan Thomas W. Lin. 2007. Manajemen Biaya Penekanan Strategis. Terjemahan Tim Penerjemah Salemba Empat. Buku 1. Edisi 3. Jakarta : Salemba Empat.

Blocher, Edward J., David E. Stout, dan Gary Cokins. 2014. Manajemen Biaya Penekanan Strategis. Terjemahan M. Y. Hamdan dan M. R. Adhi. Buku 2. Edisi 5. Jakarta : Salemba Empat.

Carter, William K. 2013. Akuntansi Biaya. Terjemahan Krista. Buku 1. Edisi 14. Jakarta : Salemba Empat.

Hansen, Don R. dan M. M. Mowen. 2000. Manajemen Biaya. Buku 2. Edisi 2. Salemba Empat. Jakarta.

Hansen, Don R. dan M. M. Mowen. 2009. Akuntansi Manajerial. Terjemahan Deny A. Kwary. Buku 1. Edisi 8. Salemba Empat. Jakarta.

Indriani, Etty. 2018. Akuntansi Manajemen. Edisi 1. ANDI. Yogyakarta.

Krismiaji dan Y. Anni Aryani. 2011. Akuntansi Manajemen. Edisi 2. Cetakan Pertama. UPP STIM YPKN. Yogyakarta. 
Mulyadi. 2014. Akuntansi Biaya. Edisi 5. Cetakan ke-12. UPP STIM YPKN Universitas Gajah Mada. Yogyakarta.

Moleong, L.J. (2011). Metodologi Penelitian Kualitatif Edisi Revisi. PT Remaja Rosdakarya. Bandung.

Restiani, Herlina. 2011. Analisis Biaya Produksi Dengan Pendekatan Theory of Constraint (TOC) (Studi Kasus Di PT. Mitra Lestari Abadi (MLA) Banyumas). Skripsi. Universitas Muhammadiyah. Surakarta.

Setyaningrum, Rina M., Muhammad F. H., 2008. Analisis Biaya Produksi Dengan Pendekatan Theory Of Constraint Untuk Meningkatkan Laba (Study Pada PG. Krebet Baru Malang). Jurnal Riset Ekonomi dan Bisnis 8(1): 26-36.

Warren, Carl S., J. M. Reeve, J. E. Duchac, Novrys Suhardianto, D. S. Kalanjati, A.A. Jusuf, C. D. Djakman. 2014. Accounting - Indonesia Adaptation. $25^{\text {th }}$ ed. Cengage Learning. New Tech Park. Terjemahan Novrys Suhardianto dan D. S. Kalanjati. 2014. Pengantar Akuntansi - Adaptasi Indonesia. Edisi 25. Salemba Empat. Jakarta. 